\title{
WestVirginiaUniversity
}

THE RESEARCH REPOSITORY @ WVU

Graduate Theses, Dissertations, and Problem Reports

2016

\section{Comprehensive analysis of the Atlantic Coast natural gas transmission line}

William David Young

Follow this and additional works at: https://researchrepository.wvu.edu/etd

\section{Recommended Citation}

Young, William David, "Comprehensive analysis of the Atlantic Coast natural gas transmission line" (2016). Graduate Theses, Dissertations, and Problem Reports. 3973.

https://researchrepository.wvu.edu/etd/3973

This Problem/Project Report is protected by copyright and/or related rights. It has been brought to you by the The Research Repository @WVU with permission from the rights-holder(s). You are free to use this Problem/Project Report in any way that is permitted by the copyright and related rights legislation that applies to your use. For other uses you must obtain permission from the rights-holder(s) directly, unless additional rights are indicated by a Creative Commons license in the record and/ or on the work itself. This Problem/Project Report has been accepted for inclusion in WVU Graduate Theses, Dissertations, and Problem Reports collection by an authorized administrator of The Research Repository @ WVU. For more information, please contact researchrepository@mail.wvu.edu. 


\title{
Comprehensive Analysis of the Atlantic Coast Natural Gas Transmission Line
}

\author{
William David Young \\ Problem Report submitted to the \\ College of Engineering and Mineral Resources \\ at West Virginia University \\ in partial fulfillment of the requirements \\ for the degree of \\ Master's Degree \\ in \\ Energy Systems Engineering \\ Radhey Sharma, Ph.D., Committee Chair \\ Roger Chen, Ph.D., Committee Co-Chair \\ Bhaskaran Gopalakrishnan, Ph.D., Committee Member \\ Statler College \\ Morgantown, West Virginia \\ 2016
}

Keywords: Natural Gas, Pipeline, Transmission Line, Atlantic Coast, Dominion Power, ACP 


\title{
ABSTRACT \\ Comprehensive Analysis of the Atlantic Coast Natural Gas Transmission Line
}

\author{
William David Young
}

\begin{abstract}
New energy sources are needed to sustain our constant need for energy as well as the development of the next generation. The Atlantic Coast Pipeline is over 600 miles in length and will provide consistent, clean energy to the energy consumers in Virginia and North Carolina from natural gas production in the states of West Virginia, Pennsylvania, and Ohio. A detailed analysis was performed looking at modern pipeline construction as well as multiple studies to determine the economic, social, and environmental impacts of this transmission line. A theoretical study was also performed comparing how this transmission line would impact the current energy market, market demand, and effect on the coal industry. Finally, this study looks at how the transmission line would impact the alternative energy sector with its peak and backup energy demand.

The results of the analysis show that with modern pipeline construction processes, land, water sources, and rare animal and plant species will be minimally disturbed. Given the capability that the transmission line to provide numerous social and economic benefits, the pipeline should be continually pursued.
\end{abstract}




\section{ACKNOWLEDGEMENTS}

I would like to express my infinite gratitude towards those whom made this problem report and Master's degree possible. Although there are far more than a list can contain, I would like to thank the following people. First, I would like to thank West Virginia University and Statler College for making this degree a possibility for myself and other candidates. Specifically, I would like to thank my committee, comprised of Dr. Sharma, Dr. Chen, and Dr. Gopalakrishnan. I would like to personally express my appreciation to Dr. Gopalakrishnan for all of the countless hours of advising and having confidence in myself and of the creation of this program. Furthermore, I would like to thank Dr. Smith and Fonda Holehouse for pushing me beyond my boundaries and helping cultivate an entrepreneurial determination to succeed. I would like to give dedication to Diffenbauch \& Hritz LLC, for giving me the opportunity to gain real life experience in the natural gas development and transmission line construction. This master's program would not have been possible without the Office of Greek Life at West Virginia University who gave me the opportunity to work as a Graduate Assistant.

Finally, I would like to personally thank my mother, Kay Young, my father, Bill Young, my brother, Robbie Young, and all the friends and family that gave me support along this venture. Without your unwavering love and support this problem report and degree would have not been possible. 


\section{TABLE OF CONTENTS}

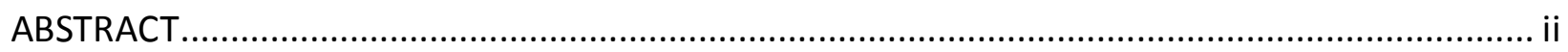

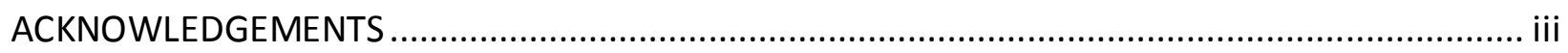

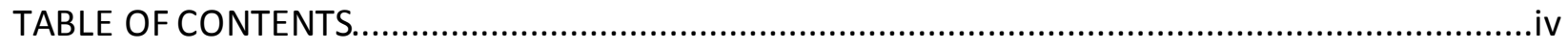

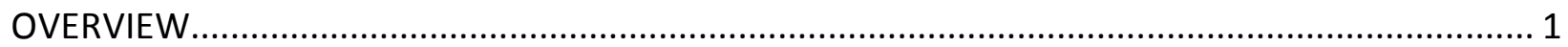

DESIGN AND ENGINEERING OF A TRANSMISSION LINE .................................................. 3

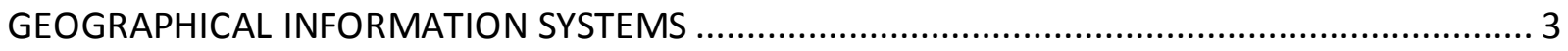

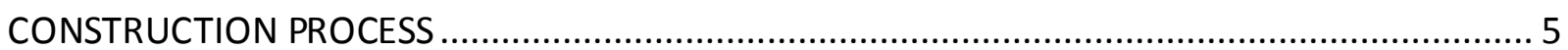

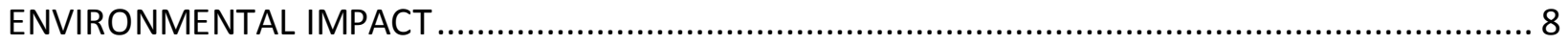

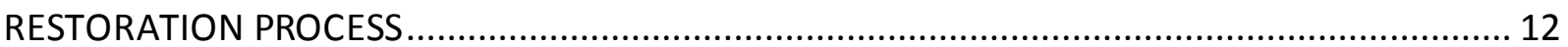

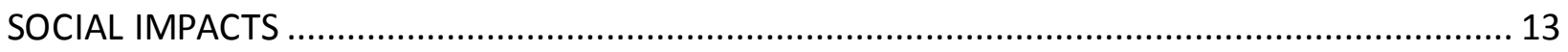

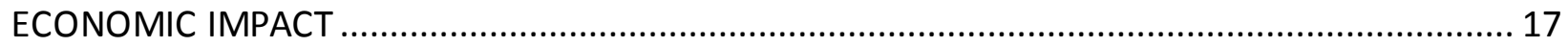

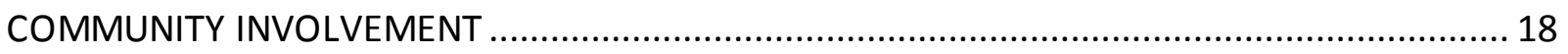

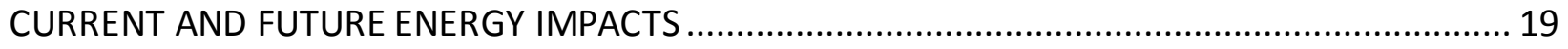

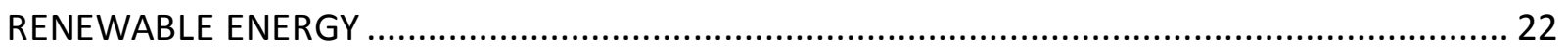

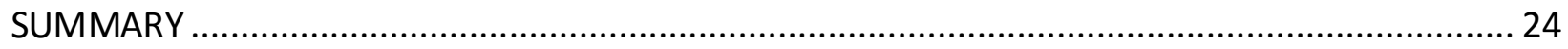

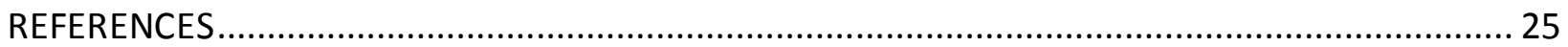




\section{TABLEOF FIGURES}

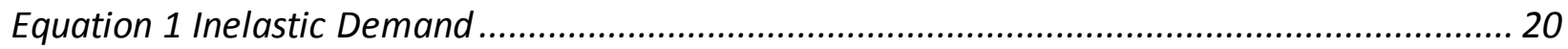

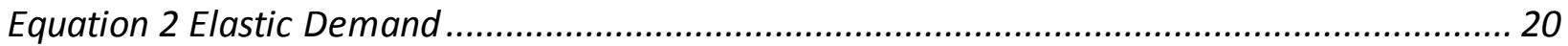

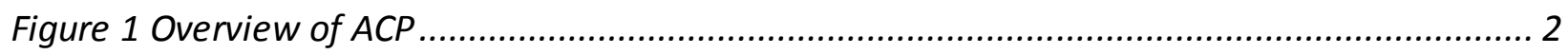

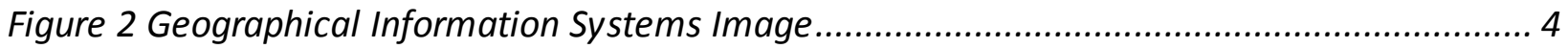

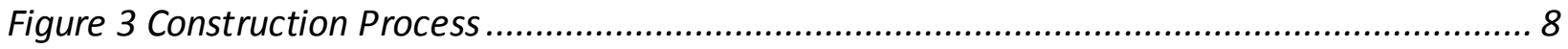

Figure 4 Environmental Wetland Delineation Map .......................................................... 9

Figure 5 FERC Environmental Review Process ................................................................. 11

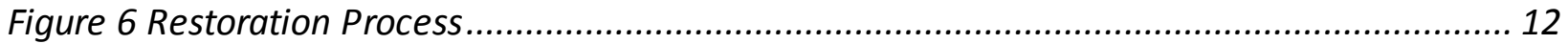

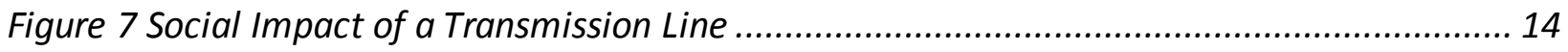

Figure 8 Average Hourly Earnings of All Employees in Pipeline Transportation Ind ustry ............ 15

Figure 9 Relationship between Pipeline Transportation Employment and Price per Gallon of

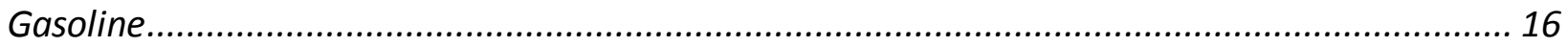

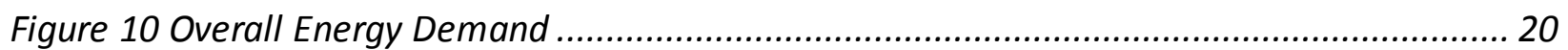

Figure 11 Theoretical Natural Gas Demand Increase ..................................................... 21

Figure 12 Theoretical Natural Gas Demand Increase on Coal Industry ................................... 22

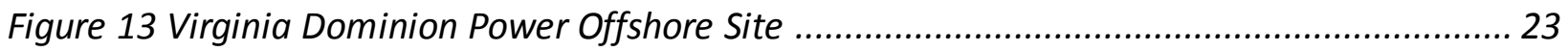




\section{OVERVIEW}

The Atlantic Coast Pipeline hereby formally known as ACP is a multi-state, 600 mile natural gas transmission line that will serve the states of West Virginia, Virginia, and North Carolina costing nearly five million dollars to construct. According to Dominion Power, this transmission line was designed for the ever growing population of these states and to fulfill the natural resources needed by public utilities, small business, and to heat local homes. The ACP will start in Harrison County, WV travel to Greensville County, VA, and into eastern North Carolina. The pipeline will have two short lateral sections that will connect Dominion Virginia Power electric generating facilities in Brunswick and Greensville Counties. An overview of the transmission line is shown in Figure 1.The capacity of the pipeline is projected to be approximately 1.5 million dekatherms or 1.5 billion cubic feet of Natural Gas per day. The formation of Atlantic Coast Pipeline, LLC, was a formation between four large U.S energy companies including Dominion Virginia Power, Duke Energy, Piedmont Natural Gas, and AGL Resources to construct, operate, and maintain the transmission line. The transmission line will provide a consistent source of clean energy at low cost for the energy consumers of Virginia and North Carolina. The pipeline will also provide a consistent consumer market for the energy producing states of West Virginia, Pennsylvania, and Ohio. (Dominion, 2016) 


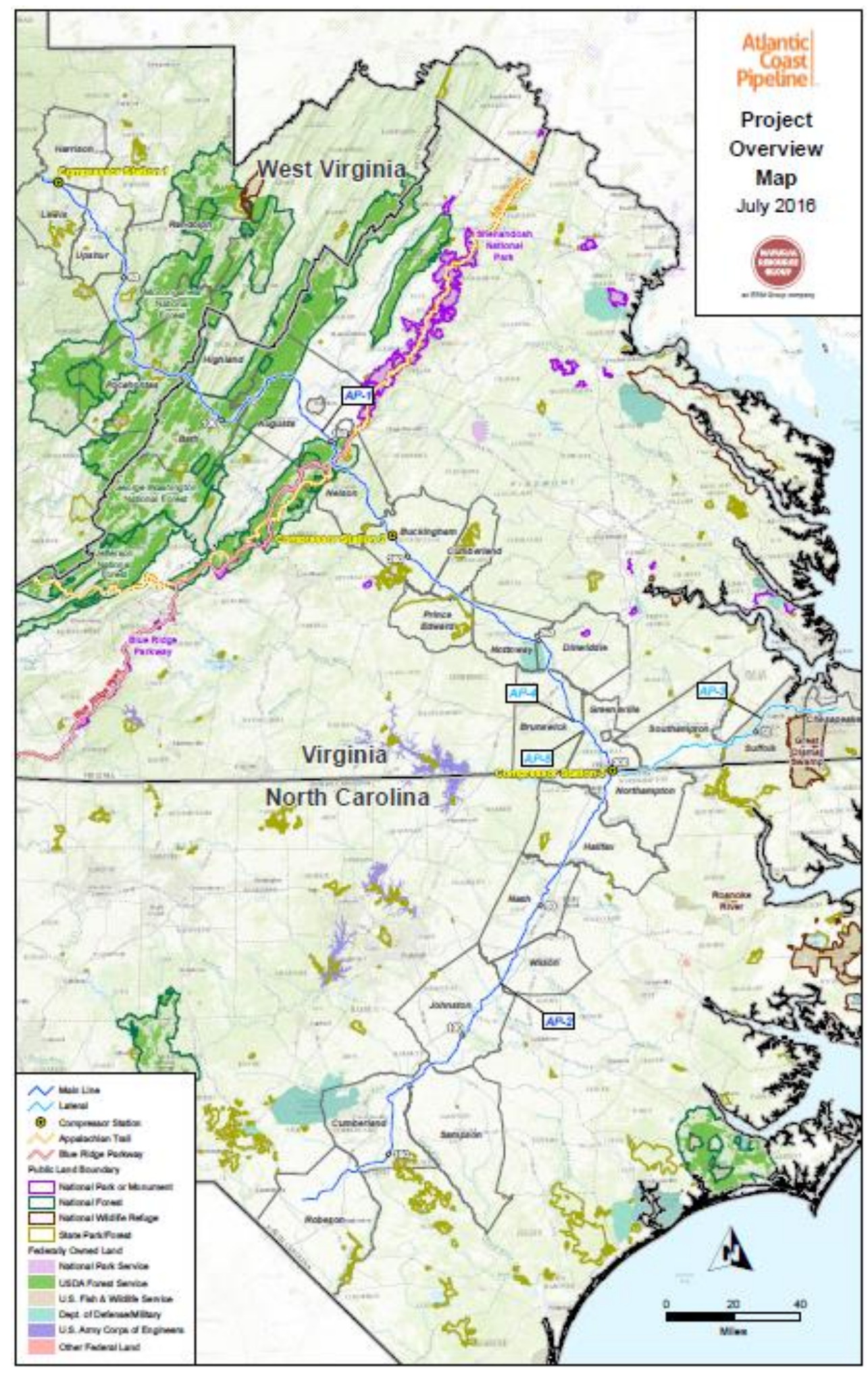

Figure 1 Overview of ACP (Dominion, 2016) 


\section{DESIGN AND ENGINEERING OF A TRANSMISSION LINE}

Before any of the construction process can begin, hours of design work must be done.

The first step in this process is that the production company's must submit a preliminary path to the consulting firm that is undertaking the design process. This preliminary path is a rough estimate to where they would ultimately like the transmission line to be laid. In order to secure this path, in-house or contracted land men will negotiate the right of way with subjected land owners in seek of a permanent easement from landowners along the route. The permanent easement would grant the production company the right to install, operate, and maintain the transmission line on the landowner's property.

\section{GEOGRAPHICALINFORMATION SYSTEMS}

Surveyors will use GIS technology to map, install, and or repair pipelines. This data allows the user to overlap multiple data sets for the purpose of manipulation and analyzation. With modern GIS systems, the user can combine digital maps, aerial photographs, satellite images, and global positioning system information. This combined with spatial-asset management systems can identify potential impacts or permitting issues by verifying visual data including roads, topography, seismic zones, and waterways. (Wint, 2015) The design company will then proceed to compiling 3-D topographic mapping as well as raster data developed by GIS to create a virtual image of the transmission line. With development of this information the engineer will have access to scaled maps and tabular data for analysis, project design, and complex decision-making without having to be on site. 


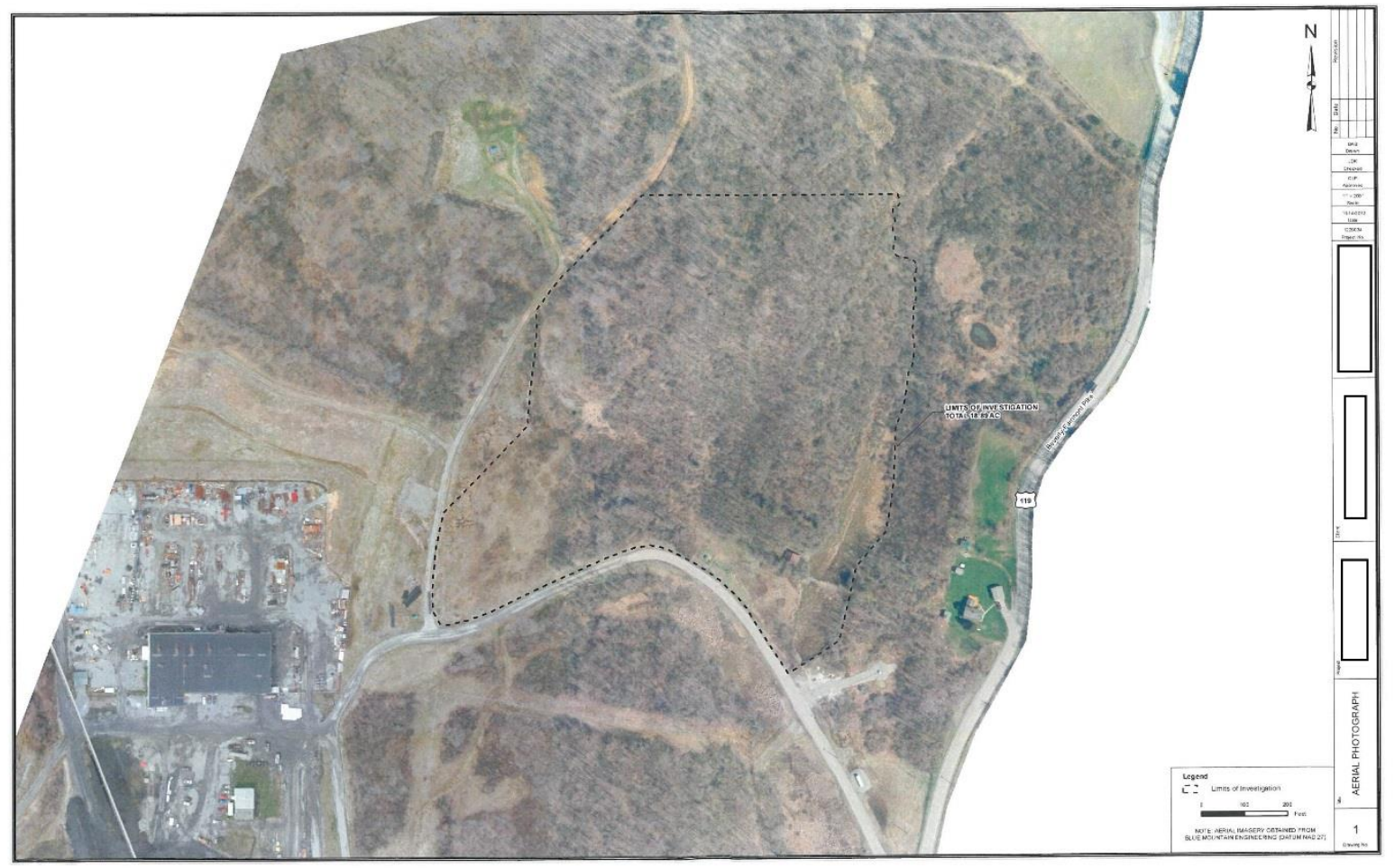

Figure 2 Geographical Information Systems Image

These 3D images allow the engineer to overlay the preliminary path obtained by the host company to better understand the terrain the transmission line will undergo. The engineer will design the transmission line with proper bends to best adapt to the terrain and production companies design standards. The transmission line will have to be designed to a depth in accordance with the Federal Energy Regulatory Council (FERC) but normally no less than 30" from the surface and approximately a 50 foot right-of-way. The engineer will also design erosion control methods by evaluating the slope and distance with predicted storm water evaluations. The designing engineer will incorporate trench plugs, water berms, compost filter sock, and other best management practices required by state and federal regulations. 


\section{CONSTRUCTION PROCESS}

Actual construction techniques vary by construction firm but all must adhere to laws and regulations and most are followed by an eight step process expressed in Figure 3 based on Dominion Power and Williams Construction Company.

1. Pre-construction survey

a. Before construction begins, a survey of environmental features along proposed pipeline segments must be mapped. Agricultural drainages, utility lines, and other stationary infrastructure are located and marked via global positioning system to prevent accidental damage during construction phase. Centerlines, outer edges of the right-of-way, and workspace is staked and taped with a known color code system.

2. Clearing and grading

a. The clearing and grading crew will clear the right-of-way of all timber and vegetation. Temporary erosion control measures such as silt sock and erosion control fence is installed to prevent erosion of disturbed soil. Once the vegetation is cleared and erosion control measures are in place, heavy equipment will follow to prepare a level working surface.

3. Trenching

a. If necessary, especially in agricultural areas, topsoil is separated from subsoil, stripped to a predetermined depth and stockpiled along the sides of the right of way. An asbuilt survey crew will then stake the center line of the trench. The construction company then uses backhoes and trenching machines to excavate the trench. According to the U.S Department of Transportation, a pipe must be buried at least 30 
inches below ground surface. The ACP will be buried to a depth of eight feet and even deeper for stream and road crossings.

4. Pipe stringing and bending

a. After being fabricated at steel mills, the pipe is then carefully examined certified by inspectors for quality control. The pipe must meet federal government and industry safety standards before being passed. The outside surface is then treated with a protective coating for erosion and rust control. According to soil conditions, the coating and pipe thickness will vary along the route.

b. The pipe is transported to a storage yard near the project location before it is moved to the right of way. Once on site, it is essential the piping is laid in accordance with the soil condition.

c. The pipe crew will use a CAD design created by the engineer to complete a series of controlled bends in the pipe to conform to the topography. A bending machine uses hydraulic pressure and a series of clamps to make these bends. All bends are monitored by an inspector to ensure they are performed in accordance to federally prescribed standards.

5. Welding, pipe coating and $\mathrm{x}$-ray inspection

a. Once the pipe is bent, pipe sections are aligned on temporary supports on the edge of the trench. Semi-automatic welding units weld the connections along each section. Conventional welding methods may have to be used at crossings and areas with substantial bends. 
b. In order to inspect the integrity of the weld, technicians use x-ray technology. Once compete, the coating is applied to the welded area to prevent rust and corrosion, before being lowered into the trench the pipe coating and welds are inspected one last time.

6. Lowering the pipe In and backfilling

a. The entire pipe assembly is lowered into the trench by side boom tractors. An as-built survey crew records the location and length of the pipeline after it is placed in the trench.

b. Subsoil is returned to the trench followed by the top soil, making sure no foreign materials or large boulders are included that might affect the integrity of the pipe. The soil is then compacted and contoured to as close to original as possible.

7. Testing

a. Before the disturbed land is restored, the sections of piped are pressure tested using a hydrostatic test. During this quality assurance test, each section is filled with pressurized water above maximum operating pressure to certify there are no leaks within the system, also ensuring the integrity of the pipe and piping components. The test water is collected and disposed of in accordance with state and federal regulations.

8. Restoration

a. Once construction is finished, the land will be restored to as close to original condition as possible. The land will be covered in hydro-seed and straw to promote vegetation 
growth. The temporary erosion control barriers are kept in place until the disturbed area is fully restored. (Constitution Pipeline, 2010) (Dominion , 2016)

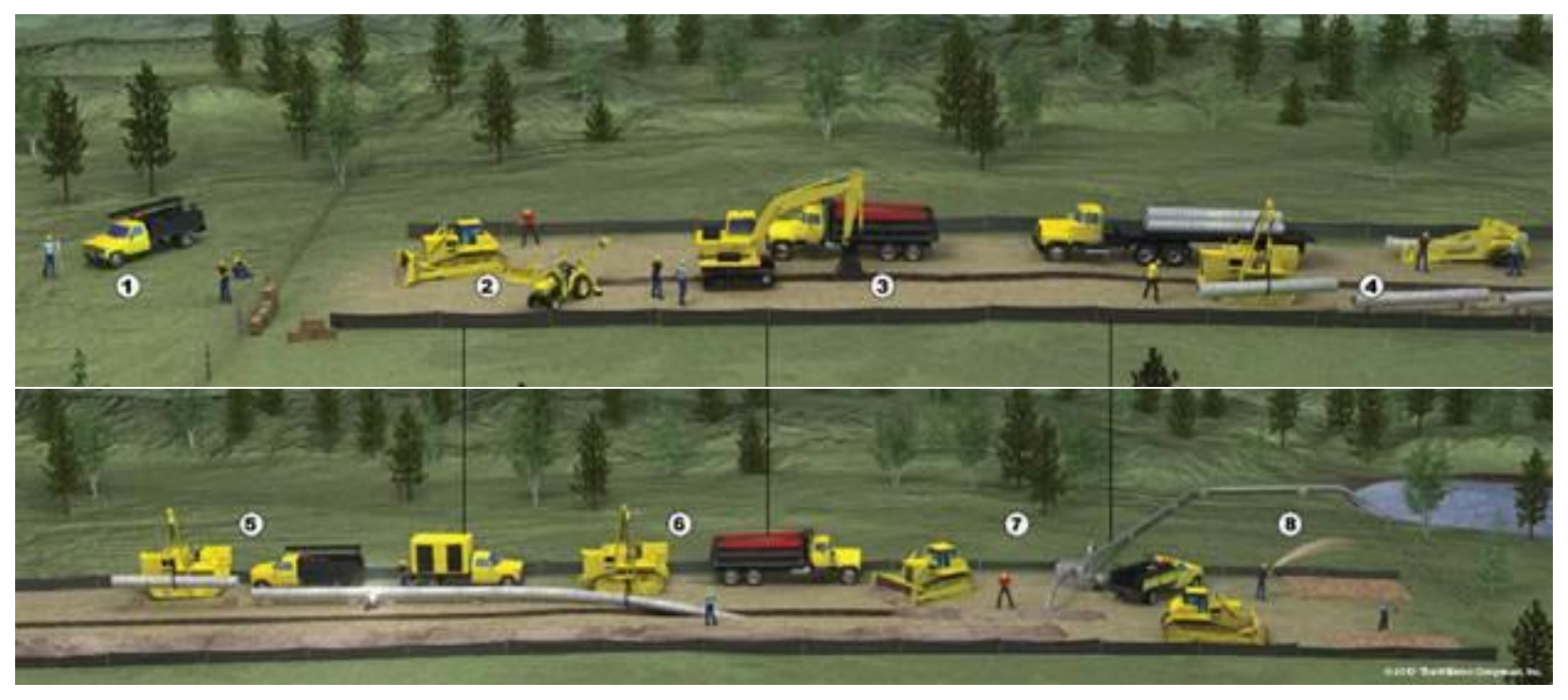

Figure 3 Construction Process (Dominion, 2016)

\section{ENVIRONMENTAL IMPACT}

The environmental impacts of a Natural Gas transmission line is substantial in the Marcellus region due to the mountainous geographic nature of the reserve. There is extensive government and state legislation that one needs to complied with due to the large amount of environmental impacts. The first thing to understand is that the work space needs to be relatively level for the equipment to work properly. This means that the overall layout of the land in many cases needs to be changed. In order to change the survey of the land, permits are needed and regulations have to be met. The transmission line also has to be accessible and have the ability to move heavy equipment to the area which causes a challenge. Changing the topography of a mountainous region will have the heaviest environmental impacts on storm water management. In order to understand the scope of the impact, the engineer must determine the limit of 
investigation (LOI) or the entire area to be studied to see if it will be affected by the design followed by the limit of disturbance or LOD: the land that can be disturbed in the formation of the site. This will be followed by a wetland and stream delineation to ensure wildlife and clean water supplies will not be contaminated by the construction process or storm water due to the change of the land contour.

To ensure the property is evaluated correctly, most companies will hire an environmental consultant to make sure that each body of water is identified and mapped. The untrained eye can easily overlook wetlands during a dry spell, but just because the land does not contain water at the moment does not mean that a considerable amount of water can pass through that region and contaminate surrounding bodies of water. An example wetland delineation study is expressed in Figure 4.

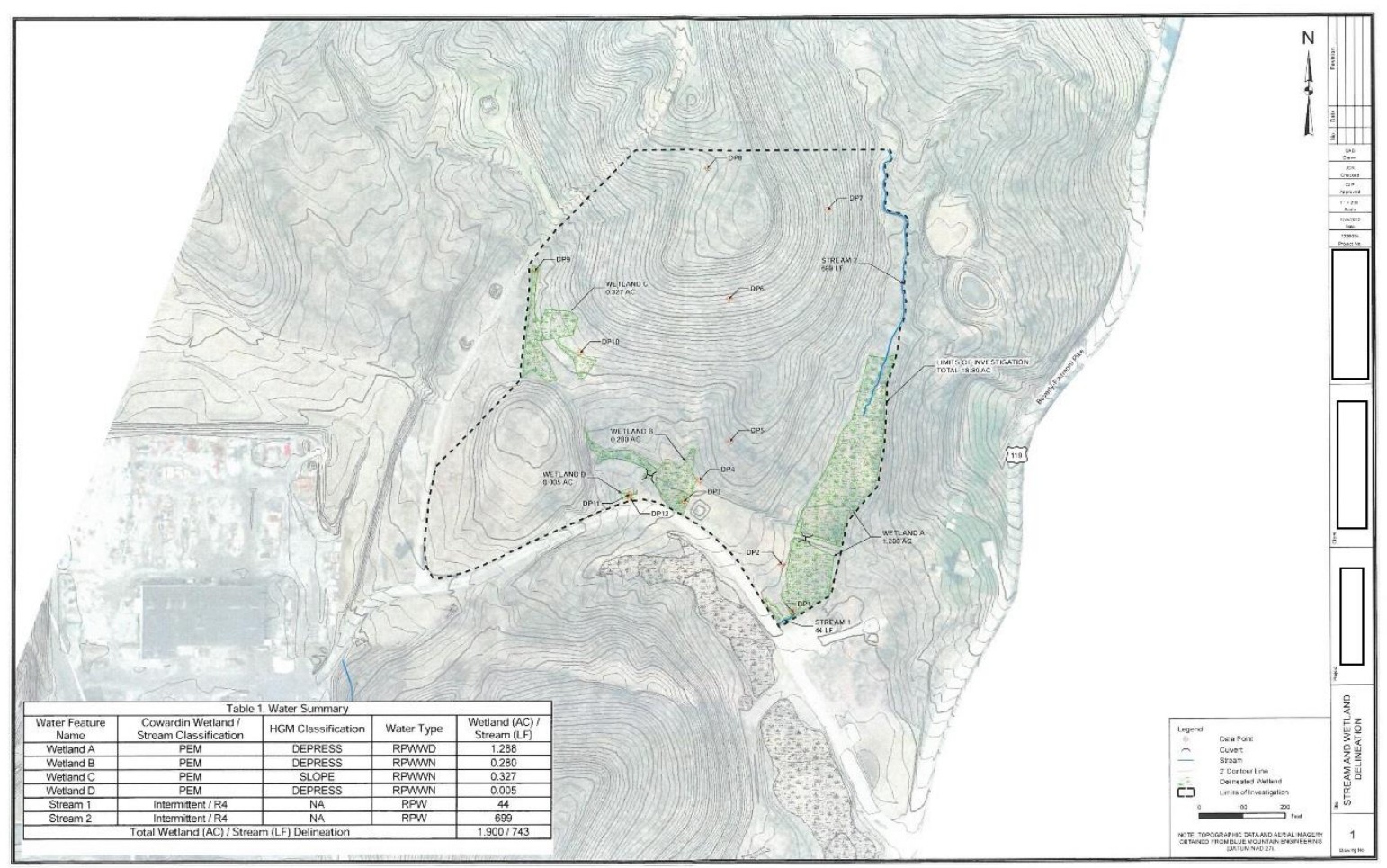

Figure 4 Environmental Wetland Delineation Map 
A job site cannot begin their operations until the proper delineation report is submitted to the U.S. Army Corps of Engineers (USACE). The USACE is in charge of regulating water safety under the Clean Water Act (CWA), which was passed in 1972 which regulates the discharging of pollutants into the waters of the United States. It also provides standards for water quality of surface waters which includes wetlands. If wetlands are going to be affected by the construction of the transmission line or be crossed by utilities or vehicles, a permit must be obtained. Once the transmission line is in place, there are other issues that must be resolved including water sourcing and waste removal. If a local water source is going to be used it is important to have the proper backflow prevention system to avoid the source from being contaminated and causing public health issues. Wetland delineation goes through different processes and documentation depending on state regulations and laws.

The development of a transmission line will change the contour of the land especially if the pipeline is placed on a slope. As the slope of the land changes the hydrology of the land would also change. This is mapped to determine where the water would accumulate. At the place of accumulation it is important to insure this new area can withstand the amount of water that will gather there. The properties of the soils are tested to ensure that soil is able to infiltrate the required amount of water. Some projects will perform an infiltration test to see how fast the soil will absorb the water. ACP will also have to prepare environmental impact statements (EIS) which addresses the environmental impacts of construction and operation of the facilities it proposes for the Atlantic Coast Pipeline. FERC will then in turn use the EIS to determine if the pipeline is 
indeed in the public convenience and necessity. This FERC environmental review process is described below:

\section{Federal Energy Regulatory Commission Environmental Review Process}

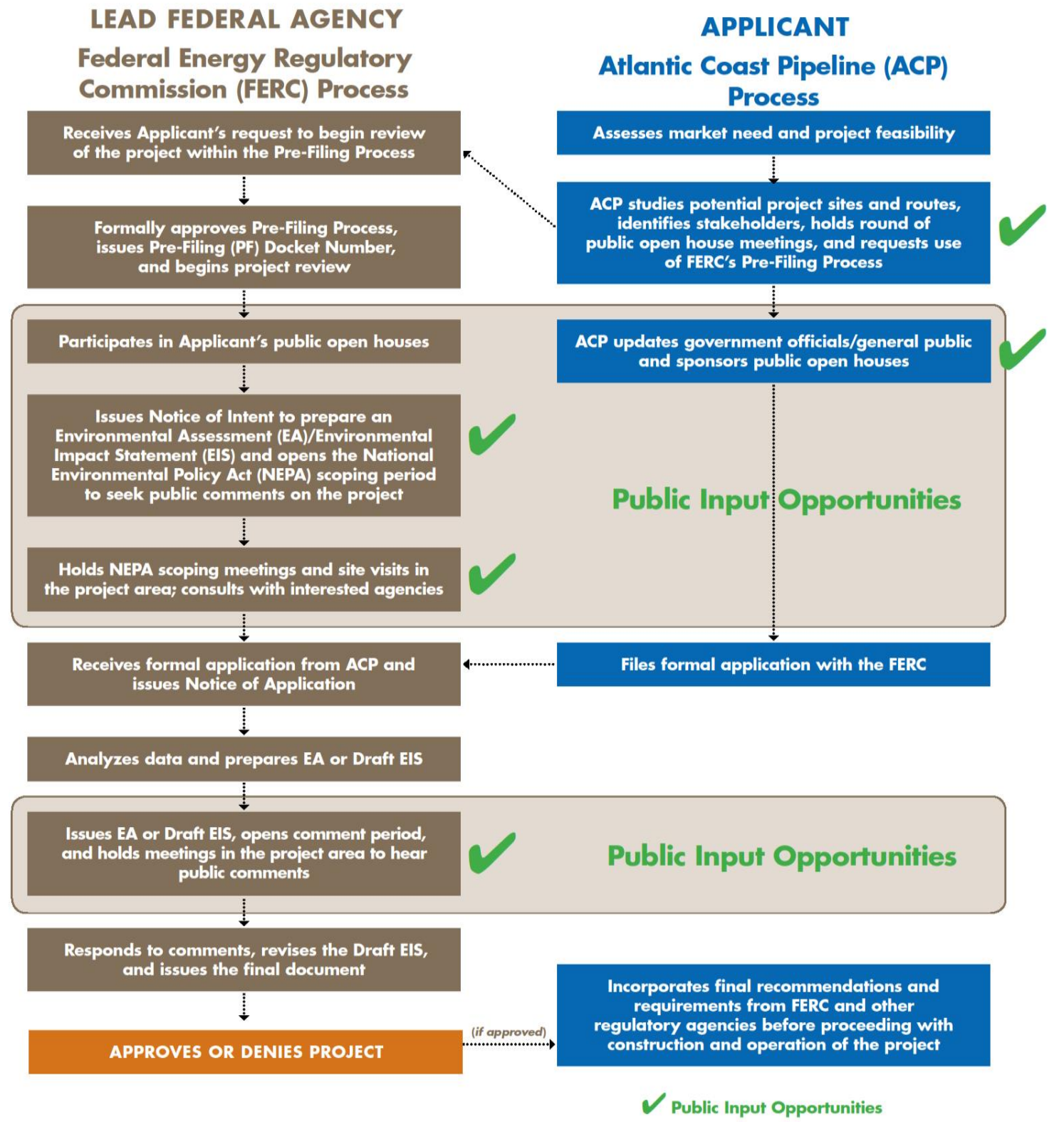

Figure 5 FERC Environmental Review Process (Dominion, 2016) 


\section{RESTORATION PROCESS}

In an effort to address environmental impact, the restoration process mentioned in the construction phase (diagram 8 ) is the most scrutinized aspect of a gas transmission line project. During this aspect of the construction phase, the land and attained right of way is restored to as close as possible to its original condition. This will be the final and permanent condition and only remanence that a transmission line has been laid in that area. In normal restoration process, the right of way will remain cleared in order to maintain and access the transmission line if a leak is exposed. The fill dirt and top soil will be back-filled to the approximate original contours of the land. The land will then be seeded with vegetation native to the land via hand seed or hydro seeding. This will be covered in either light mulch or straw to promote vegetation and decrease the possibility of erosion. Once the vegetation has matured there is minimal signs of an actual transmission line as shown in Figure 5 which shows a before, during, and after views of the construction process.

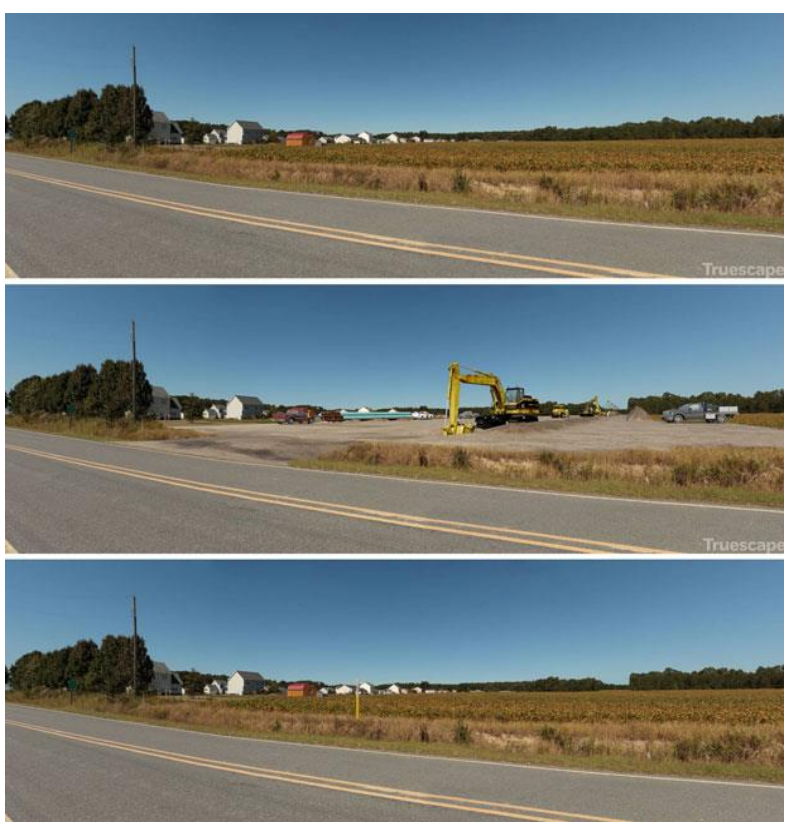

Figure 6 Restoration Process (Dominion, 2016) 


\section{SOCIAL IMPACTS}

According to Rio Declaration, human beings are at the center of concerns for sustainable development. The best way therefore to understand the social impact of any infrastructure in a society is to develop a framework that embodies the evaluation of all impacts of the infrastructure on humans and on all the ways in which people and communities interact with their socio-cultural, economic and biophysical surroundings (Nations, 1992). This will involve broad assessment of areas such as: aesthetic impacts; archaeological and cultural heritage impacts (both tangible and intangible); community impacts; cultural impacts; demographic impacts; development impacts, gender and diversity impacts; health and mental health impacts ; and impacts on indigenous rights. Furthermore these assessments could include infrastructural impacts, institutional impacts; leisure and tourism impacts; political impacts (human rights, governance, democratization etc.); poverty; psychological impacts; resource issues (access and ownership of resources); impacts on social and human capital; and other impacts on societies.

As with any complex industrial process, development of natural gas transmission line offers its own unique social benefits as well as negative impact on the host community. In rural regions, large increase in transport traffic and oil and gas workers can dramatically alter a community's way of life. Although local economies stand to benefit, local infrastructure of such region can quickly become degraded, and inflationary pressures can make regions unaffordable to long-time residents. Additionally, continuous operation of transmission lines can create disturbing light, and noise pollution with negative health effects. Major psychosocial stressors such as the impact of cultural diversity and integration due to increased population growth, child 
labor, workplace violence, public safety and security are also strongly associated with the development of transmission line that will have effect on social structure of both the community and individual levels as shown in the Figure 7 below.

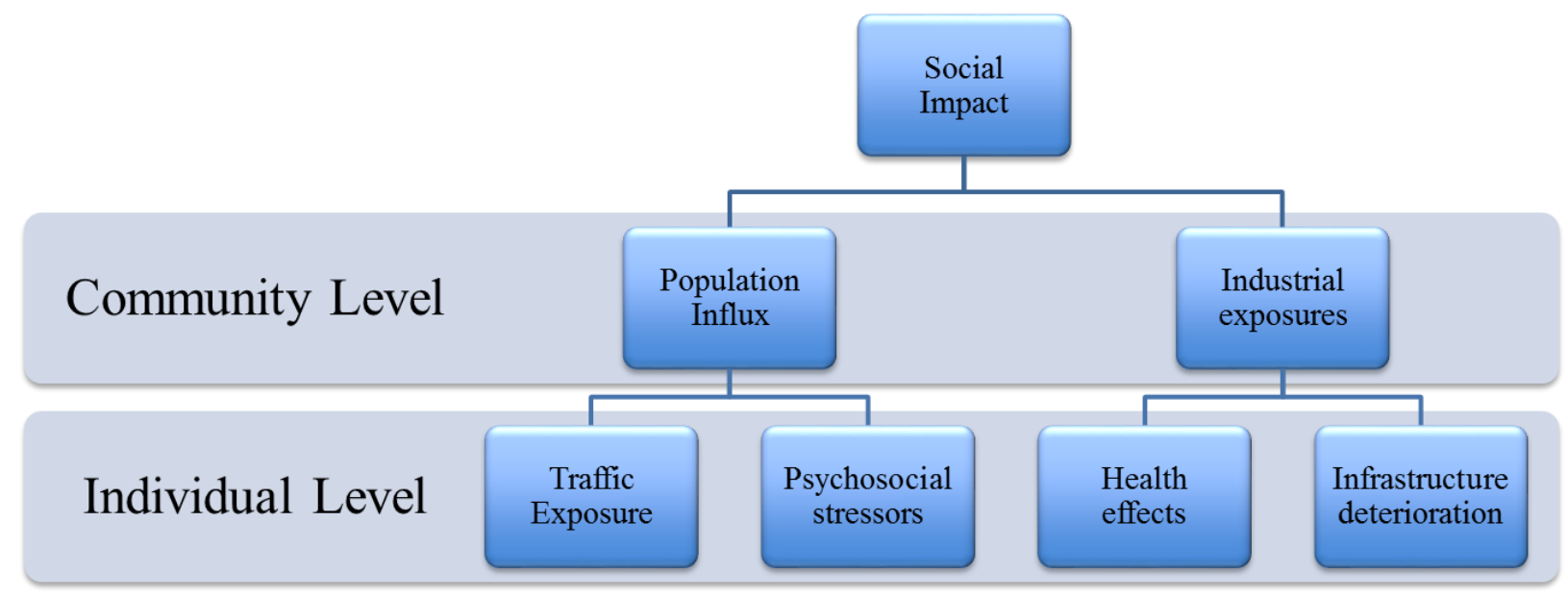

Figure 7 Social Impact of a Transmission Line

Although, there are potentially mitigating factors, such as increased tax revenue or income for community and provision of basic amenities in the form of social responsibility, nearby residents may complain of odors, noise, light, or psychosocial stress from declining land values or decreased housing availability. The development of intra community differences in the perception of risk and rewards may also lead to stress in some residents. Local stressors such as water availability, ground level ozone, and water quality may also become regional issues if it affects adjacent locations.

An example of a health and mental health impacts include Industrial incidents, malfunctions worksite and traffic accidents put workers at increased risk of exposure to fires, explosions, and uncontrolled chemical releases. Bureau of Labor Statistics data indicate that the fatality rate for pipeline transportation workers between 2011 and 2014 had less than eight 
confirmed fatalities directly related to pipeline transportation. This however could have been offset by the hourly earnings. The average hourly earnings for pipeline transportation was more than $\$ 42$ dollars per hour in August 2016 and has increased dramatically from about $\$ 26$ dollars per hour in 2006, shown in Figure 8. (Bureau of Labor Statistics , 2016)

\section{Employment, Hours, and Earnings from the Current Employment Statistics survey (National)}
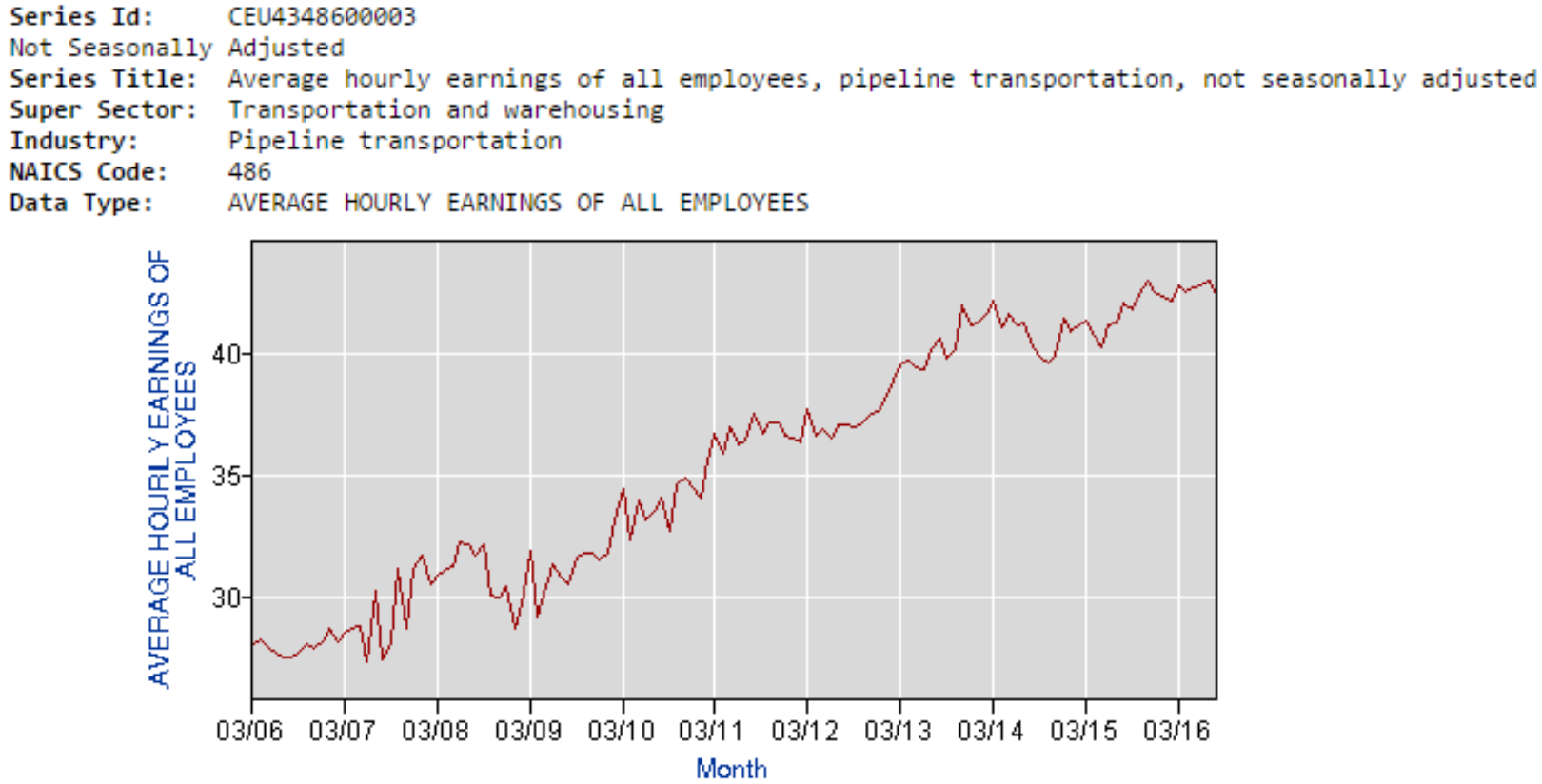

Figure 8 Average Hourly Earnings of All Employees in Pipeline Transportation Industry (Bureau of Labor Statistics, 2016)

According to the United States Bureau of Labor Statistics (2016) the average of pipeline transportation employment in the year 2012 was around 44,000 employees which was four years after the natural gas "boom". The average number of pipeline employees grew substantially to its peak of 49,300 in the year 2015 where it took a slight downturn to 48,700 in the elapsed months of 2016. Both the growth of employment in this sector as well as growth in hourly 
earnings has had a constructive cumulative effect on social areas where negative social impacts have occurred due to a transmission line construction.

Evaluating the overall statistics of why there may have been such a large increase in employment computes to the substitution between petroleum and natural gas. Comparing the average number of pipeline transportation employment to the average price per gallon of gasoline in Figure 9 one could conclude that there is a direct correlation between pipeline employment and gas prices. This can be seen as the price of a gallon of gasoline began to decrease employment of pipeline transportation increased. In the later months of 2016 we have begun to see a slight increase in price of gasoline at around $\$ 2.30$ which could be a forecasted prediction as seen in the decline of employment between 2015 and 2016.

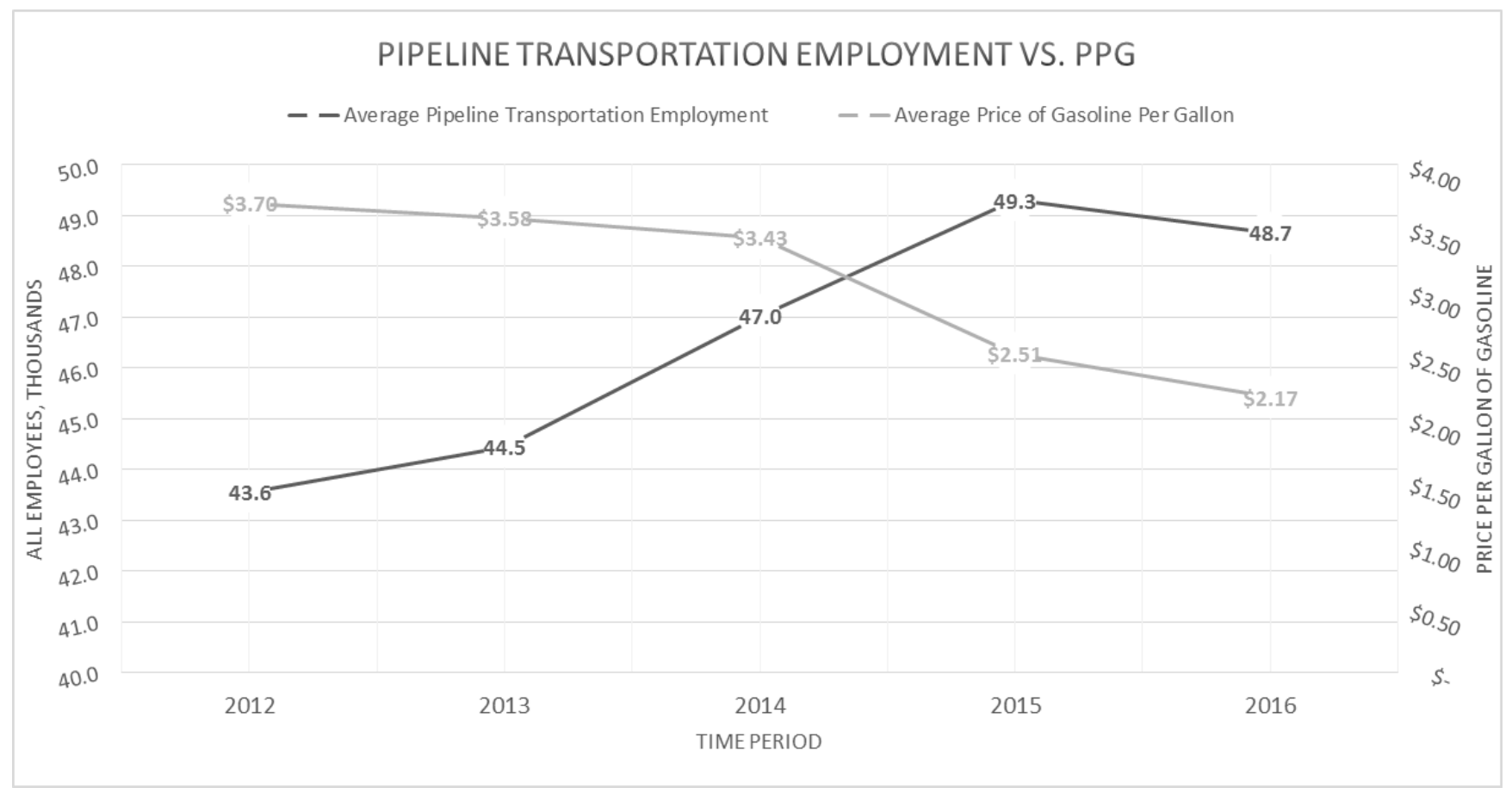

Figure 9 Relationship between Pipeline Transportation Employment and Price per Gallon of Gasoline, Statistics from (Bureau of Labor Statistics , 2016) 


\section{ECONOMICIMPACT}

The oil and gas production has significantly increased in the United States. Consider shale gas production for the past decade, from 2006 to 2012 it has increased from 1 trillion cubic feet to 9.7 trillion cubic feet. However, this increase has positive economic impact on our society, from the improvement of businesses to the economic development of a community in general. According to Pennsylvania Department of Environmental Protection, for the past 10 year more than 2000 site have been drilled to expand natural gas construction. Furthermore, there is more than 100 companies and subcontractor that has moved to Pennsylvania because the natural gas drilling construction that created more than 12.5 thousand full time jobs. It shows a significant increase in the job opportunities and helps the growth of the local economy. All these facts shows the economic relationship between natural gas construction and jobs opportunity in the Marcellus region as well as across the United States. This kind of natural gas devel opment is what has made the Atlantic Coast Transmission a viable and economically necessary project.

The Atlantic Coast Pipeline will have independent impacts on natural gas market area, electricity prices, as well as the impacts on regional economies. This transmission line will expand the natural gas supplies located in Marcellus and Utica shale plays from consumers in West Virginia and Pennsylvania to Virginia and North Carolina who have already subscribed to nearly 91\% of the ACP's 1.5 billion cubic feet per day (Bcf/d) capability. ACP has declared to use the 1.5 million dekatherms to meet the needs of its consumers in Virginia and North Carolina and not to export this valuable resource oversees. In a report prepared by ICF international for Dominion Transmission, Inc., concluded that the largest economic stimulus would be located in Virginia and 
North Carolina. ICF predicted that between 2019 and 2038 the net annual average energy cost savings between these states would be over 377 million dollars impacting both households and commercial industries. The economic activity related to the ACP and its energy savings would contribute more than 2,200 permanent full-time jobs and over 2,873 one time construction jobs bringing in \$131 million in annual labor income on just the permanent jobs (ICF International, 2015).

According to a Chmura Economics \& Analytics report, the one-time construction activity of the Atlantic Coast Pipeline could inject an annual average of $\$ 456.3$ million into the economy of the three-state combined region of West Virginia, Virginia, and North Carolina with the possible support of 2,873 annual jobs in the region from 2014 to 2019 . When the pipeline is in full operation, the project is estimated to have an annual impact in the three-state region of $\$ 69.2$ million that can support 271 regional jobs from 2019 onward. The project could also generate significant tax revenue for three state governments. The report did not quantify other significant benefits that would have been derived from construction of the project, including additional opportunities for new manufacturing, stability in energy prices, and environmental improvements through the increased use of cleaner-burning natural gas as a source of electric generation. (Chmura Economics and Analytics, 2014)

\section{COMMUNITYINVOLVEMENT}

A normally overlooked economic impact of the ACP is the community involvement of Virginia Dominion Power. Dominion Power has stepped up and made multiple donations, gifts, 
and grants. A gift of $\$ 1.1$ million dollars was split between three conservancy preserves: Bear Rocks Preserve, West Virginia: Warm Springs Mountain Preserve, Virginia: and Nags Head Woods Preserve. North Carolina, to advance conservation efforts afore of construction. A grant of $\$ 50,000$ was granted to the James River Association for a "Floating Classroom". The James River Expedition was to help students and teachers to participate in a variety of activities related to water quality and biological monitoring. Finally, there were two more grants of $\$ 30,000$ and $\$ 10,000$ to Paul D. Camp Community College and the Boys \& Girls Clubs of Johnston County respectively. The Paul D. Camp Community College Grant was formed to create a robotics and mechatronics laboratory at the college to support the two new programs offered in the electronics department. The grant to the Boys and Girls Club was to help support summer programming and operations of the non-profit based club that helps build character and strengthen life skills of the community's youth.

\section{CURRENTAND FUTURE ENERGY IMPACTS}

To understand how the Atlantic Coast Transmission line will affect our current energy demand we first must understand how theoretical but predictable economic work. Demand for overall energy will always be inelastic due to the fact that we will always have a demand. A demand curve is considered inelastic when it is not very sensitive to price changes. In other words, a one percent change in price will result in less than a one percent change in quantity demanded with $\Delta Q_{d}$ expressing the change in quantity demanded and $\Delta P$ representing a change in price. 


$$
D_{\text {inelastic }}=\frac{\Delta Q_{d}}{\Delta P}=\frac{\left(Q_{c}-Q_{p}\right)}{\left(P_{c}-P_{p}\right)}<-1
$$

Equation 1 Inelastic Demand

$$
D_{\text {elastic }}=\frac{\Delta Q_{d}}{\Delta P}=\frac{\left(Q_{c}-Q_{p}\right)}{\left(P_{c}-P_{p}\right)}>-1
$$

\section{Equation 2 Elastic Demand}

Following this economic reasoning we can predict that as this new, reliable energy source enters the Virginia and North Carolina markets, its price impact will be minimal as shown in Figure 10. As the price of natural gas reduces shown by the shift from $P_{1}$ to $P_{2}$ it will shift the new quantity demanded from $Q_{1}$ to $Q_{2}$ creating a new supply/demand equilibrium from $S_{1}$ to $S_{2}$.

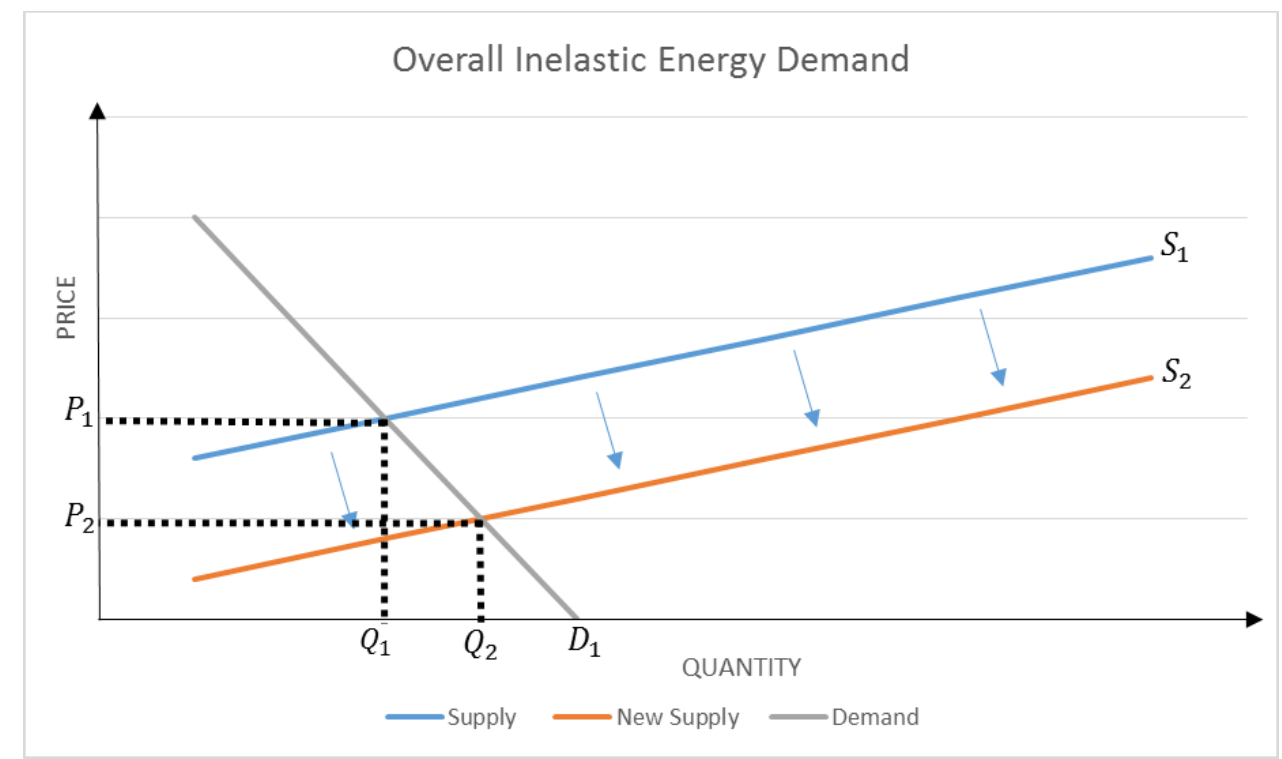

Figure 10 Overall Energy Demand

Overall market price is not the only economic benefit of the ACP. Other than the nuclear energy produced by the Carolinas a majority of the energy is imported. By adding new gas delivery capacity into the Virginia and North Carolina regions this will help mitigate the competition and price pressure that market conditions in other areas of the country impose on 
gas supplies serving these areas. By creating a new, more reliable source of energy for these regions, it will allow an energy cost savings and allow consumers in these areas to spend more money in other sectors of the economy. This in turn would stimulate new job creation, labor income, tax revenue, and gross state product.

By looking at our nation's movement towards clean fuel and natural gas being at the front of this movement as well as more and more power plants in the ACP service region switching to natural gas, the theoretical natural gas demand would increase. This theoretical increase in Figure 11 with a shift of demand outward from $D_{1}$ to $D_{2}$ subsequently creating a new price, demand equilibrium as shown by the change in $P_{1}$ to $P_{2}$ and $Q_{1}$ to $Q_{2}$.

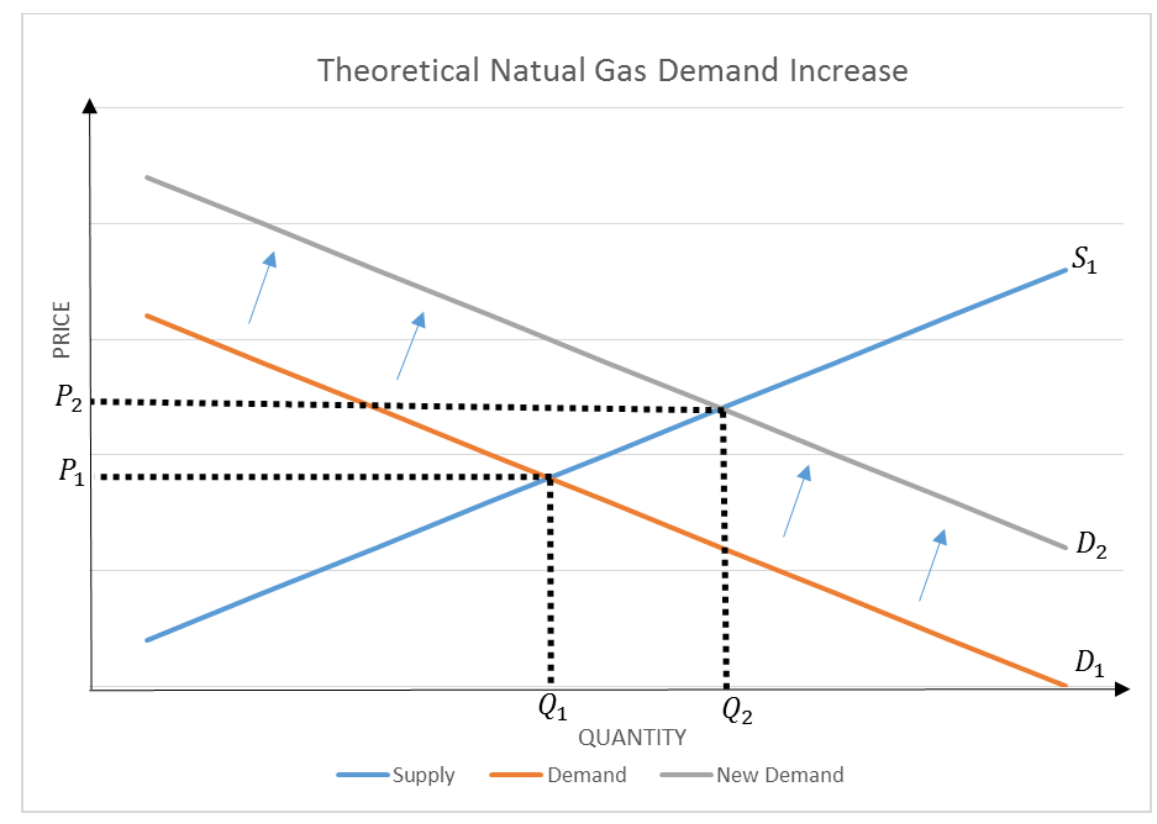

Figure 11 Theoretical Natural Gas Demand Increase

As mentioned in Figure 11, primarily coal fired power plants are now switching to natural gas because coal is a direct substitute to Natural Gas meaning that two goods could be used for 
the same purpose. If the price of one good increases, the demand for the substitute is likely to rise creating a positive cross elasticity of demand. Comparatively, as demand for natural gas goes up, it would shift demand for coal down, subsequently reducing the equilibrium demand price and quantity for coal from $P_{1}$ to $P_{2}$ and $Q_{1}$ to $Q_{2}$ shown in Figure 12 . Although this would have a negative impact on coal producing states including West Virginia, there was a decrease in demand for coal prior to the large development of natural gas due to the movement in our government towards clean energy.

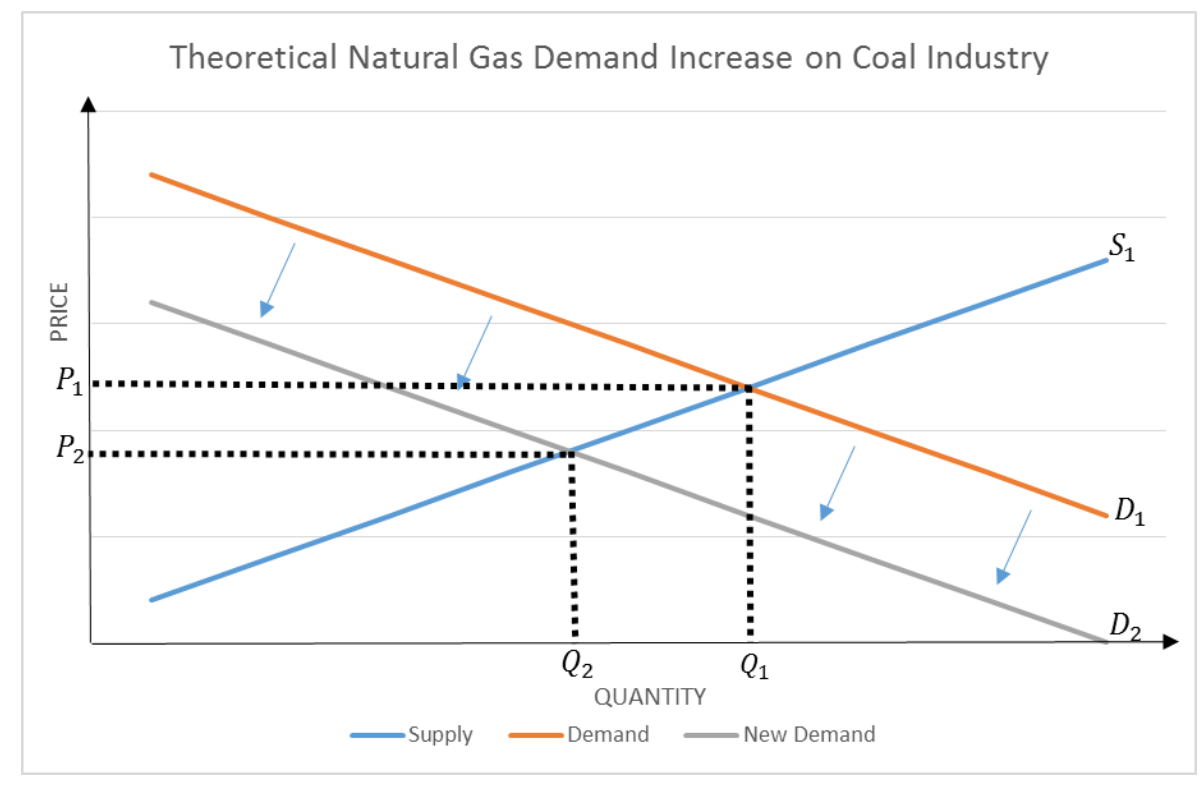

Figure 12 Theoretical Natural Gas Demand Increase on Coal Industry

\section{RENEWABLE ENERGY}

Although not intuitively, the Atlantic Coast Transmission Line will in fact, support renewable power generation in the Virginia and North Carolina regions. North Carolina's energy profile varying from $32.6 \%$ nuclear, $31.4 \%$ coal, $28.3 \%$ natural gas, and $7.1 \%$ renewable, the ACP will help increase form natural gas as at least the co-primary power source in the region. The use 
of nuclear, coal, and natural gas as conventional peaking power would be used to res pond quickly to upward or downward electric supply or demand changes in electric demand. Renewable energy sources including solar, wind, and offshore energy sources create clean, renewable power on an intermittent basis to offset the volatility in the demand or supply of power changes. Dominion Virginia Power, a company along with Duke Energy, Piedmont Natural Gas, and AGL Resources, combined with the ACL is leasing an 112,800 acre parcel of federal land off the coast of Virginia. Figure 13. This land (ocean waters) will be used to develop an offshore wind turbine farm, generating up to 2,000 megawatts of electricity, approximately enough to sustain 700,000 homes. This offshore renewable energy project will be able to work in cogeneration with the natural gas supplied by the Atlantic coast transmission line. (Dominion, 2013)

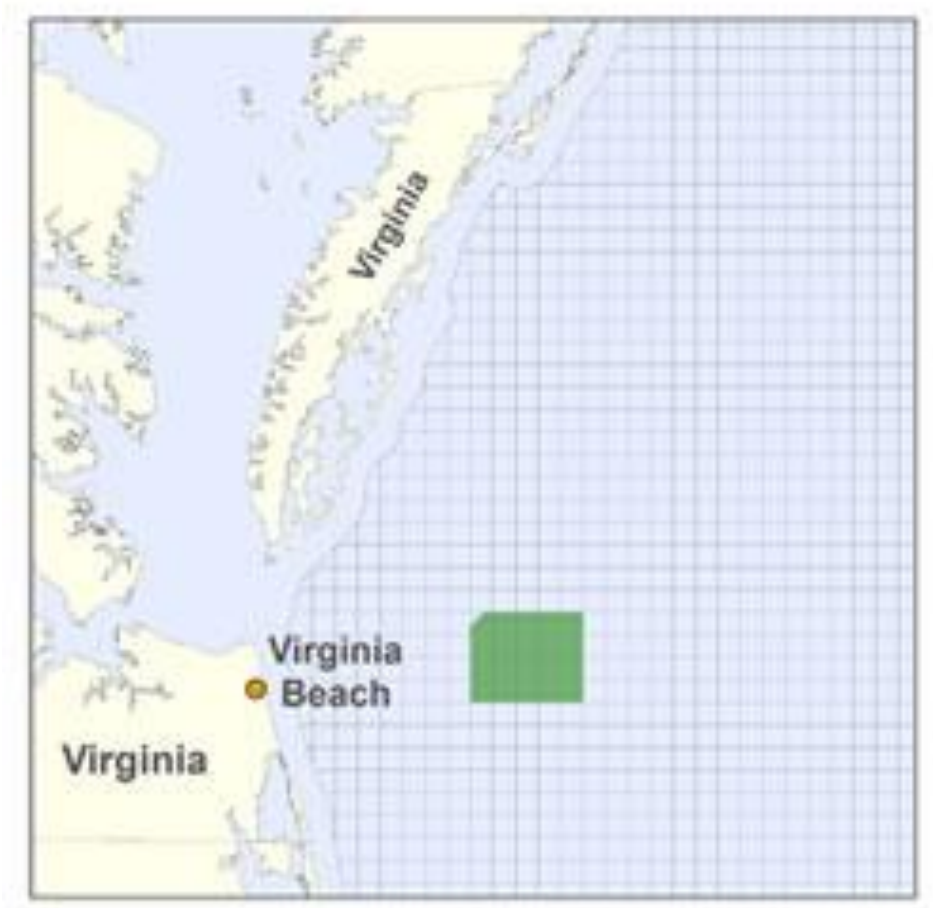

Figure 13 Virginia Dominion Power Offshore Site (Commercial Lease for Wind Energy Offshore Virginia, n.d.) 


\section{SUMMARY}

The Atlantic Coast Natural Gas Transmission line will generate significant benefits both socially and economically to the energy consumers in West Virginia, Virginia, and North Carolina regions. It is anticipated that there will be an annual average of $\$ 456.3$ million in economic benefits for the three states including supporting 2,873 jobs. The construction alone will produce and estimated $\$ 2.7$ billion and require over 17,000 new jobs. The net energy cost savings to Virginia and North Carolina consumers could average $\$ 377$ million per year with West Virginia benefiting from a stable product consumer. In total, ACP has the potential to generate $\$ 7.5$ billion in energy cost savings, create 45,000 jobs, and generate $\$ 2.6$ billion labor income, and $\$ 4.4$ billion in gross state product for Virginia and North Carolina from 2019 to year 2038. (ICF International , 2015)

The booming natural gas discovery in the United States and across the world is increasing the usage of Natural Gas for electricity generation. Environmentally, natural gas creates much less $\mathrm{CO} 2, \mathrm{SO} 2$, and NOX emission than its direct substitute, coal. By switching to natural gas for our primary power production over coal, it will reduce our rate of greenhouse gas production, slowing the rate of global warming. The economic, social, and environmental benefits of the Atlantic Coast Pipeline greatly outweigh small amount of environmental disturbance it takes to construct this transmission line. The current trend is that natural gas is playing an increasingly important role in supplying domestic produced energy. The Atlantic Coast Pipeline and other natural gas transmission lines are a critical component to ensure dependability of domestic energy infrastructure in the United States. 


\section{REFERENCES}

Adgate, D. J. (2015). Public Health and Energy Development:. Rocky Mountain Academy of Occupational and Environmental Medicine, Inc. Colorado: Colorado School of Public Health.

Bureau of Labor Statistics . (2016, October 14). Pipeline Transportation: NAICS 486. Retrieved from United States Department of Labor Burear of Labor Statistics: http://www.bls.gov/iag/tgs/iag486.htm

Chmura Economics and Analytics . (2014). The Economic Impact of the Atantic Coast Pipeline in West Virginia, Virginia, and North Carolina. . Richmond: Chmura.

Commercial Lease for Wind Energy Offshore Virginia. (n.d.). Retrieved from Bureau of Ocean Energy Management : https://www.boem.gov/Renewable-Energy-Program/StateActivities/VA/Commercial-Lease-for-Wind-Energy-Offshore-Virginia.aspx

Constitution Pipeline. (2010). How Williams Builds Pipelines. Retrieved from www.constitutionpipeline.com: https://constitutionpipeline.files.wordpress.com/2012/05/construction1.pdf

Dominion . (2016). Atlantic Coast Pipeline, Pipeline Construction . Retrieved from www.dom.com/corporate: https://www.dom.com/library/dom com/pdfs/gastransmission/atlantic-coast-pipeline/acp-pf3-pipeline-construction.pdf?la=en

Dominion. (2013). Dominion Virginia Power Wins Federal Offshore Wind Auction. Retrieved from http://dom.mediaroom.com/2013-09-04-Dominion-Virginia-Power-Wins-FederalOffshore-Wind-Auction

Dominion. (2016). Atlantic Coast Pipeline. Retrieved from www.dom.com/corporate: https://www.dom.com/corporate/what-we-do/atlantic-coast-pipeline/maps

ICF International . (2015). The Economic Impacts of the Atlantic Coast Pipeline. Fairfax: ICF International .

Nations, U. (1992). Rio Declaration on Environment and Development . Lexmercatoria.

Wint, D. (2015, December 21). The Technological Future of Pipeline Integrity. Retrieved from Audubon: http://www.auduboncompanies.com/technologic al-future-pipeline-integrity/ 